\title{
Thermal Stability and Devitrification Behavior of Ternary Ni-Nb-Ti and Quaternary Glassy Alloys Containing Noble Metals
}

\author{
Takeyuki Shimada $^{1, *}$, Dmitri V. Louzguine ${ }^{1}$, Junji Saida ${ }^{2}$ and Akihisa Inoue ${ }^{1}$ \\ ${ }^{1}$ Institute for Materials Research, Tohoku University, Sendai 980-8577, Japan \\ ${ }^{2}$ Center for Interdisciplinary Research, Tohoku University, Sendai 980-8578, Japan
}

\begin{abstract}
The devitrification of $\mathrm{Ni}_{60} \mathrm{Nb}_{25} \mathrm{Ti}_{15}$ glassy alloy has been investigated by X-ray diffraction (XRD), differential scanning and isothermal calorimetry and transmission electron microscopy (TEM). The primarily crystallized phase was a cubic $\mathrm{Ni}(\mathrm{Ti}, \mathrm{Nb})$ phase with a lattice parameter of $0.293 \mathrm{~nm}$. A Ni ${ }_{3} \mathrm{Nb}$ phase follows precipitation of the $\mathrm{Ni}(\mathrm{Ti}, \mathrm{Nb})$ phase. The cubic $\mathrm{Ni}(\mathrm{Ti}, \mathrm{Nb})$ phase undergoes partial transformation to $\mathrm{Ni}_{4} \mathrm{Ti}_{3}$ phase. These cubic $\mathrm{Ni}(\mathrm{Ti}, \mathrm{Nb})$ phases disappear at the equilibrium conditions.

The supercooled liquid region $\left(\Delta T_{\mathrm{x}}\right)$ of the $\mathrm{Ni}_{60} \mathrm{Nb}_{25} \mathrm{Ti}_{15}$ glassy alloy was extended to $64 \mathrm{~K}$ with the addition of $\mathrm{Pt} \mathrm{The} \mathrm{Ni}_{55} \mathrm{Nb}_{25} \mathrm{Ti}_{15} \mathrm{Pt}_{5}$ glassy alloy rods with diameters up to $2 \mathrm{~mm}$ were formed by mold casting. Pt and the other noble metals additions do not alter devitrification of $\mathrm{Ni}_{60} \mathrm{Nb}_{25} \mathrm{Ti}_{15}$ glassy alloy.
\end{abstract}

(Received October 25, 2004; Accepted January 6, 2005)

Keywords: nickel-niobium-titanium alloy, noble metals, glass-forming ability, thermal stability, bulk glassy alloy, devitrification behavior

\section{Introduction}

Bulk glassy alloys were obtained by stabilization of the supercooled liquid against crystallization in a various multicomponent metallic alloys, at the relatively slow cooling rate of less than $100 \mathrm{~K} / \mathrm{s}$ from liquid state. ${ }^{1-4)}$ The stabilization has enabled the production of bulk glassy alloys in the thickness range of $1-100 \mathrm{~mm}$ by using various casting processes. These alloys are promising materials for structural applications as they exhibit high mechanical strength, high fracture toughness and good corrosion resistance. ${ }^{2)}$

$\mathrm{Ni}$-based bulk glassy alloys were obtained in $\mathrm{Ni}-\mathrm{Zr}-\mathrm{Ti}$ $\mathrm{Si},{ }^{5,6)} \mathrm{Ni}-\mathrm{Zr}-\mathrm{Ti}-\mathrm{Sn},{ }^{7)} \mathrm{Ni}-\mathrm{Nb}-\mathrm{Ti},{ }^{8)} \mathrm{Ni}-\mathrm{Nb}-\mathrm{Zr}-\mathrm{Ti}{ }^{9)}$ systems. $\mathrm{Ni}_{60} \mathrm{Nb}_{25} \mathrm{Ti}_{15}$ bulk glassy alloy has an ultimate compressive strength of $3085 \mathrm{MPa}$ and exhibits plastic deformation of about $2 \%$. Bulk glassy alloy with high tensile fracture strength of $2700 \mathrm{MPa}$ a critical diameter of $3 \mathrm{~mm}$ has been produced in a multicomponent $\mathrm{Ni}-\mathrm{Nb}-\mathrm{Ti}-\mathrm{Zr}-\mathrm{Co}-\mathrm{Cu}$ system. ${ }^{10)}$

At the same time, the devitrification process of Ni-based glassy alloys has been poorly studied. The clarification of thermal stability and devitrification processes is of great importance for the glassy alloys which are expected to be used as structural materials. On the other hand, the increase of the thermal stability can be achieved by the proper alloying additions. However, an addition of an ordinary metal or a half-metal has already been performed.

Recently, it has been reported that noble metals (M) addition ( $\mathrm{Pd}, \mathrm{Ag}, \mathrm{Pt}, \mathrm{Au})$ have changed thermal stability and altered devitrification pathway of $\mathrm{Cu}^{11,12)}$ and $\mathrm{Zr}$-based ${ }^{13,14)}$ glassy alloys forming an icosahedral quasicrystalline phase.

In this paper, we present the results on the devitrification process of the $\mathrm{Ni}_{60} \mathrm{Nb}_{25} \mathrm{Ti}_{15}$ glassy alloy (with a supercooled liquid region $\Delta T_{\mathrm{x}}$ of $54 \mathrm{~K}$ and a reduced glass transition temperature $\left(T_{\mathrm{g}} / T_{1}\right)$ of 0.622$)$, as well as the influence of $\mathrm{M}$ $(\mathrm{Pd}, \mathrm{Ag}, \mathrm{Pt}, \mathrm{Au})$ addition on the thermal stability and glassforming ability of the $\mathrm{Ni}_{60-x} \mathrm{Nb}_{25} \mathrm{Ti}_{15} \mathrm{M}_{x}$ glassy alloys.

*Graduate Student, Tohoku University,

E-mail: takeyuki@imr.tohoku.ac.jp

\section{Experimental Procedure}

The alloy ingots were prepared by arc-melting a mixture of pure metals in an argon atmosphere. From these alloy ingots, ribbon samples with a cross-section of about $0.02 \times 1 \mathrm{~mm}^{2}$ were prepared by a single roller melt-spinning method in an argon atmosphere. Bulk cylindrical samples of $2 \mathrm{~mm}$ or $3 \mathrm{~mm}$ in diameter were prepared by copper mold casting in an argon atmosphere. The thermal stability was investigated by differential scanning calorimetry (DSC) at a heating rate of $0.67 \mathrm{~K} / \mathrm{s}$ and the liquidus temperature $\left(T_{1}\right)$ was measured by differential thermal analysis (DTA) at a cooling late of $0.067 \mathrm{~K} / \mathrm{s}$. Isothermal differential calorimetry tests were also performed. The structure was examined by X-ray diffraction (XRD) and transmission electron microscopy (TEM). Mechanical properties were measured with an Instron testing machine at a strain rate of $5 \times 10^{-4} \mathrm{~s}^{-1}$. The gauge dimension for the compressive test was $2 \mathrm{~mm}$ in diameter and $5 \mathrm{~mm}$ in height.

\section{Results}

\subsection{Devitrification of $\mathrm{Ni}_{60} \mathrm{Nb}_{25} \mathrm{Ti}_{15}$ glassy alloy}

Figure 1 shows DSC and isothermal calorimetry curves of the melt-spun $\mathrm{Ni}_{60} \mathrm{Nb}_{25} \mathrm{Ti}_{15}$ glassy ribbon samples scanned at $864 \mathrm{~K}$ and $874 \mathrm{~K}$. The DSC trace in Fig. 1(a) shows a variation of the baseline at about $864 \mathrm{~K}$ related to a glasstransition and two exothermic peaks.

Two overlapped peaks are observed in the isothermal calorimetry curves (Fig. 1(b)) corresponding to the first DSC peak (Fig. 1(a)). This indicates that two phase transitions might have happened simultaneously. We applied the heat treatment regime 1 (HT1) (see Fig. 1(b)) to the sample. It was subjected to argon-flow cooling after the achieving of the top of the first exothermic peak of the isothermal calorimetry curve (see Fig. 1(b)).

Figure 2 shows the XRD data of the glassy alloy heat-treated at some temperatures. Cubic $\mathrm{Ni}(\mathrm{Ti}, \mathrm{Nb})$ phase with a lattice parameter of $a=0.293 \mathrm{~nm}$ and orthorhombic $\mathrm{Ni}_{3} \mathrm{Nb}$ phase with the lattice parameter of $a=0.511 \mathrm{~nm}, b=$ 

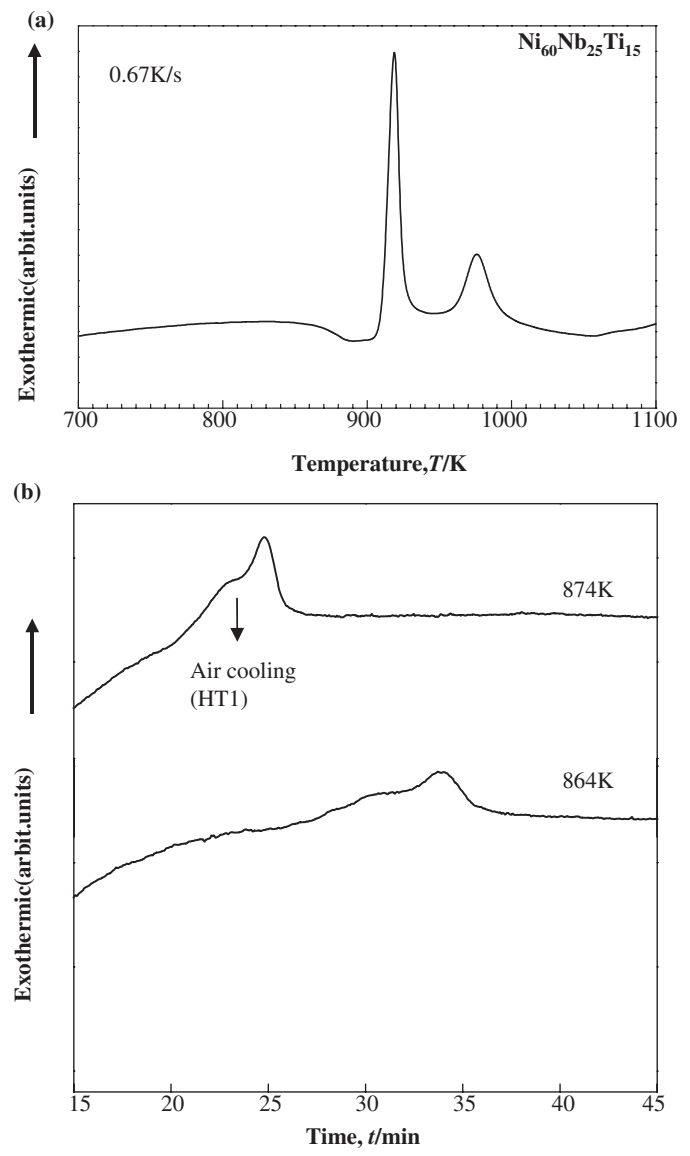

Fig. 1 (a) DSC curve of $\mathrm{Ni}_{60} \mathrm{Nb}_{25} \mathrm{Ti}_{15}$ glassy alloy and (b) isothermal calorimatry curves of $\mathrm{Ni}_{60} \mathrm{Nb}_{25} \mathrm{Ti}_{15}$ glassy alloy at $874 \mathrm{~K}$ and $864 \mathrm{~K}$.

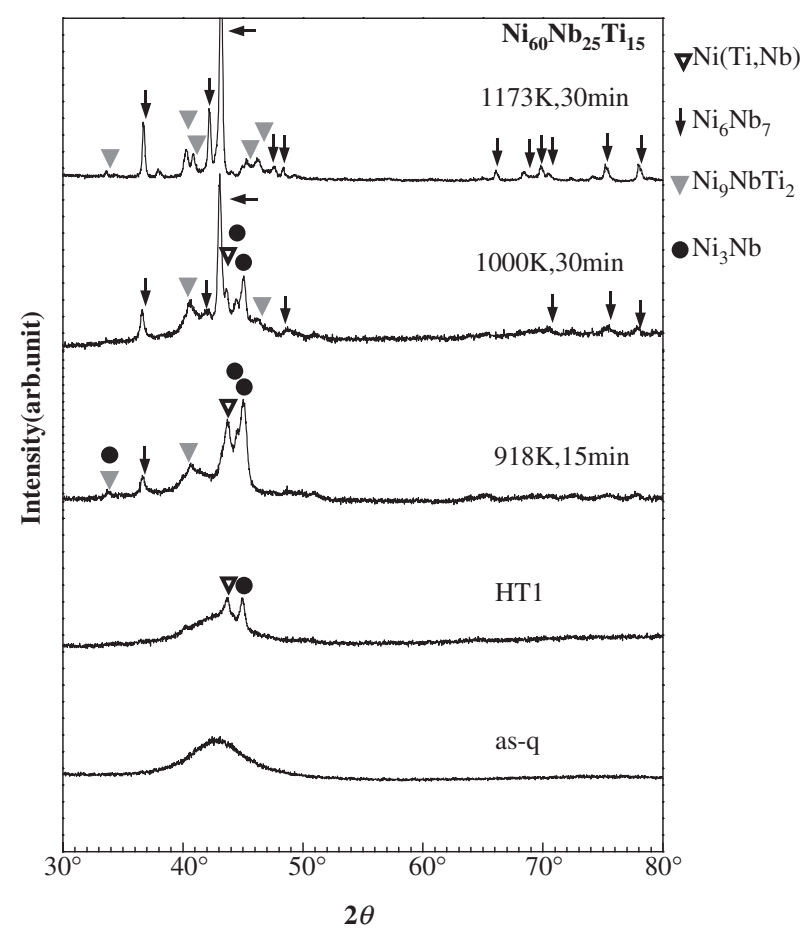

Fig. 2 XRD patterns of $\mathrm{Ni}_{60} \mathrm{Nb}_{25} \mathrm{Ti}_{15}$ glassy alloy heat-treated at some temperatures. "as-q" means as-quenched, HT1 is heat treatment regime 1.

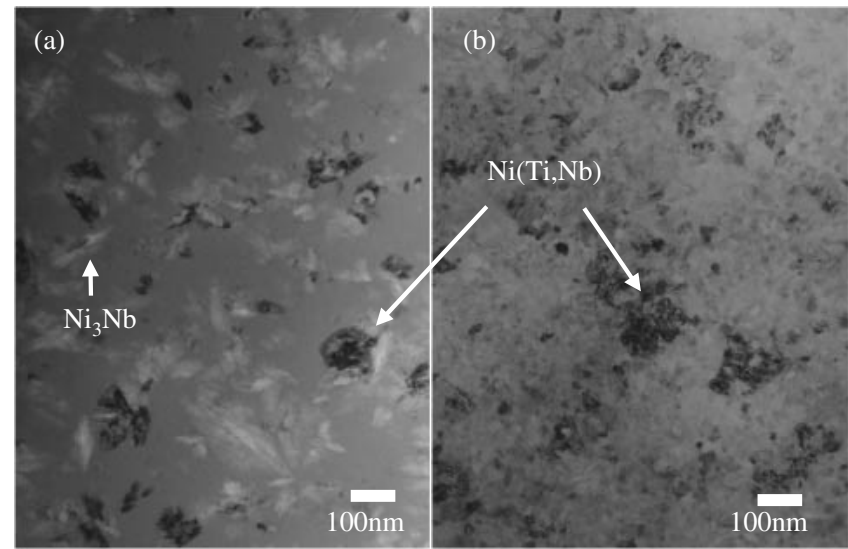

Fig. 3 Bright-field TEM image of the $\mathrm{Ni}_{60} \mathrm{Nb}_{25} \mathrm{Ti}_{15}$ alloy. annealed by at HT1 regime (a) and annealed at $918 \mathrm{~K}$ for $15 \mathrm{~min}$ (b).

0.424 and $c=0.454 \mathrm{~nm}$ are observed in the sample heat treated in the HT1 regime. These phases also exist after the completion of the first exothermic peak. However, these phases disappeared after heating for $30 \mathrm{~min}$ at $1173 \mathrm{~K}$ and one can observe two equilibrium phases, i.e., hexagonal $\mathrm{Ni}_{6} \mathrm{Nb}_{7}$ phase with lattice parameters of $a=0.489$ and $c=$ 2.66 and hexagonal $\mathrm{Ni}_{9} \mathrm{NbTi}_{2}$ phase with lattice parameters of $a=0.513 \mathrm{~nm}$ and $c=0.421 \mathrm{~nm}$. The $\mathrm{Ni}_{9} \mathrm{NbTi}_{2}$ phase appears to precipitate prior to $\mathrm{Ni}_{6} \mathrm{Nb}_{7}$ one. Moreover, the equilibrium orthorhombic $\mathrm{Ni}_{11} \mathrm{Nb}_{3} \mathrm{Ti}_{6}$ phase with the lattice parameters of $a=0.879 \mathrm{~nm}, b=1.187 \mathrm{~nm}$ and $c=0.881$ $\mathrm{nm}$ also precipitates at $1173 \mathrm{~K}$.

Figure 3 shows the TEM structures of the HT1 sample and the sample annealed at $918 \mathrm{~K}$ for $15 \mathrm{~min}$. The cubic $\mathrm{Ni}(\mathrm{Ti}, \mathrm{Nb})$ particles have an equiaxed morphology with a diameter of about $100 \mathrm{~nm}$ while the $\mathrm{Ni}_{3} \mathrm{Nb}$ particles have a rod-shaped morphology with a diameter of about $30 \mathrm{~nm}$ and a length of about $100 \mathrm{~nm}$. The energy-dispersive X-ray (EDX) analysis of these particles gave a composition of $\mathrm{Ni}_{64} \mathrm{Nb}_{19} \mathrm{Ti}_{16}$ which can be regarded as a solid solution of $\mathrm{Nb}$ in the NiTi phase substituting Ti.

Figure 4 shows the selected-area electron diffraction patterns (SAEDP)s of the equiaxed phase. The equiaxed phase in partially transformed to $\mathrm{R}_{\overline{3}} \mathrm{Ni}_{4} \mathrm{Ti}_{3}$ phase. SAEDPs of the $\mathrm{Ni}_{3} \mathrm{Nb}$ rod-shaped phase is shown in Fig. 5. Formation of R-phase is also possible.

\subsection{Change of the thermal stability by the addition of noble-metals}

Figure 6 shows the DSC curves of the amorphous Nibased alloys containing 5 at $\%$ of $\mathrm{Pd}, \mathrm{Ag}$, Pt or $\mathrm{Au}$. The glass transition temperature $\left(T_{\mathrm{g}}\right)$, crystallization temperature $\left(T_{\mathrm{x}}\right)$ and supercooled liquid region $\left(\Delta T_{\mathrm{x}}=T_{\mathrm{x}}-T_{\mathrm{g}}\right)$ are shown in Fig. 7. The $\Delta T_{\mathrm{x}}$ increased to $64 \mathrm{~K}$ when the sample contains 5 at $\% \mathrm{Pt}$. In order to investigate the effect of Pt on $\Delta T_{\mathrm{x}}$, the $\mathrm{Pt}$ content was changed. Figure 8 shows DSC curves of the melt-spun $\mathrm{Ni}_{60-x} \mathrm{Nb}_{25} \mathrm{Ti}_{15} \mathrm{Pt}_{x}(x=0 \sim 7.5)$ glassy alloys. The $T_{\mathrm{g}}, T_{\mathrm{x}}$ and $\Delta T_{\mathrm{x}}$ as a function of $\mathrm{Pt}$ content are shown in Fig. 9. It is seen that the rise in $T_{\mathrm{g}}$ and $T_{\mathrm{x}}$ is proportional to $\mathrm{Pt}$ content but the maximum of $\Delta T_{\mathrm{x}}$ of $64 \mathrm{~K}$ is attained at 5 at $\%$ Pt. This alloy has slightly lower $T_{\mathrm{g}}$ and higher $T_{\mathrm{x}}$ (see Fig. 9). 

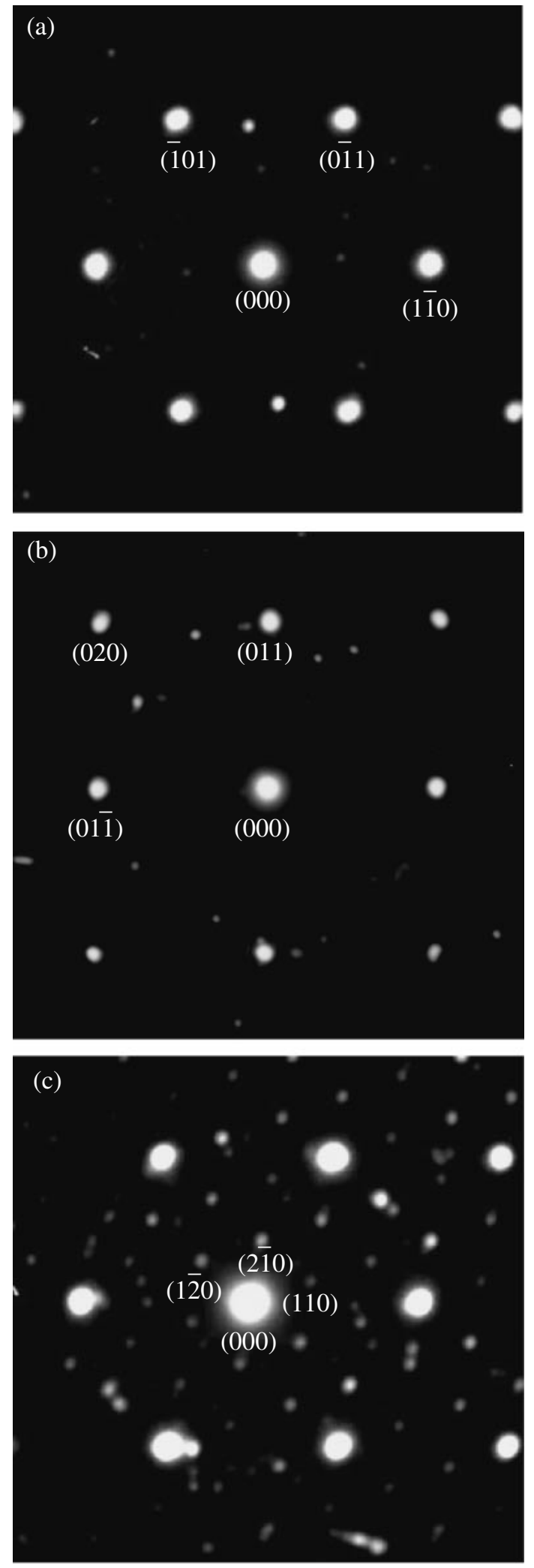

Fig. 4 Selected-area electron diffraction patterns of $\mathrm{Ni}(\mathrm{Ti}, \mathrm{Nb})$ phase (a) [111], (b) [100], and $\mathrm{Ni}_{4} \mathrm{Ti}_{3}$ phase (c) [001].

\subsection{Formation of bulk glassy alloys}

Figure 10 shows XRD patterns of $\mathrm{Ni}_{60-x} \mathrm{Nb}_{25} \mathrm{Ti}_{15} \mathrm{Pt}_{x}$ $(x=2.5 \sim 7.5)$ bulk samples with a diameter of $2 \mathrm{~mm}$ produced by copper mold casting. The XRD pattern of the sample containing 5 at\% Pt consists only of a broad diffrac-
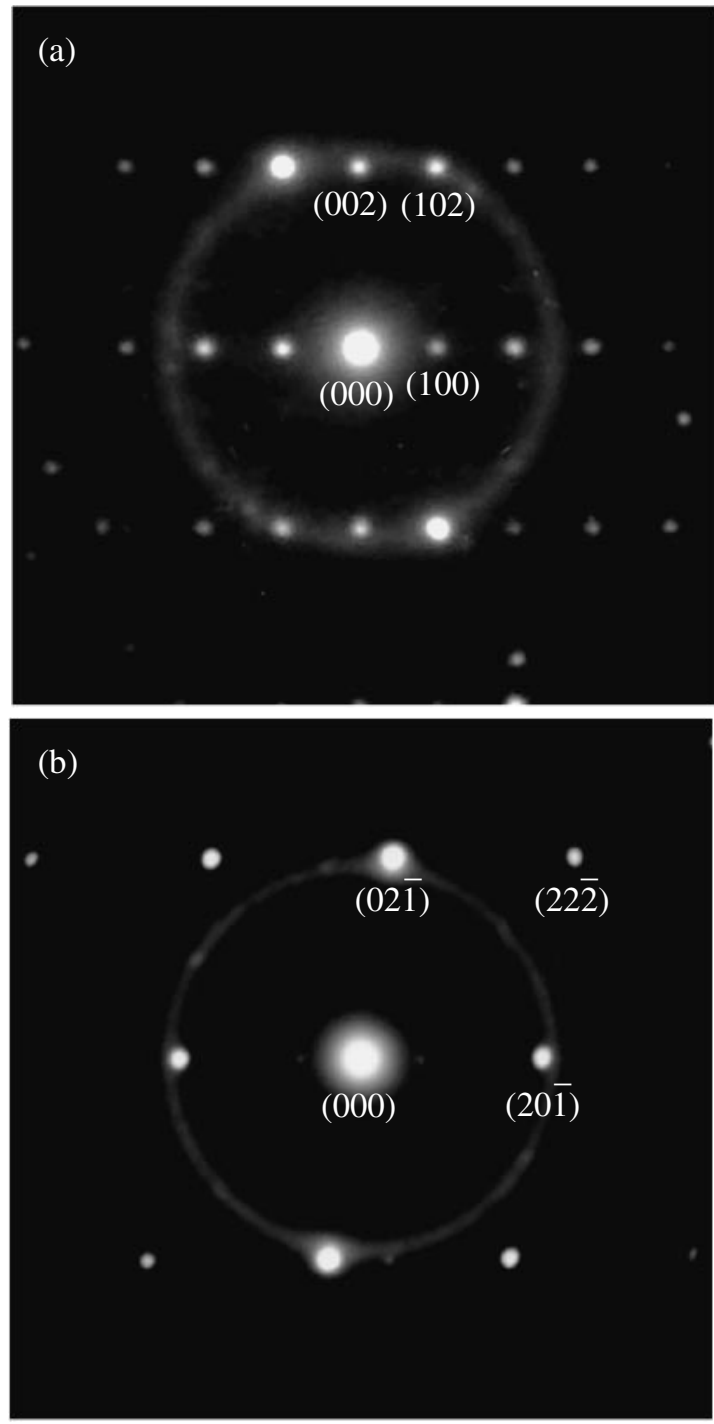

Fig. 5 Selected-area electron diffraction pattern of $\mathrm{Ni}_{3} \mathrm{Nb}$ phase. Zone axes (a) [010] and (b) [112].

tion peaks indicating the formation of an amorphous single phase. The peaks of $\mathrm{Ni}(\mathrm{Ti}, \mathrm{Nb})$ phase are observed in the assolidified rods containing $2.5 \mathrm{at} \% \mathrm{Pt}$ and 4 at $\% \mathrm{Pt}$. A $\mathrm{Ni}_{55} \mathrm{Nb}_{25} \mathrm{Ti}_{15} \mathrm{Pt}_{5}$ bulk alloy rod of $3 \mathrm{~mm}$ in diameter was also produced but the structure was crystalline.

Figure 11 shows DSC curves of the $\mathrm{Ni}_{55} \mathrm{Nb}_{25} \mathrm{Ti}_{15} \mathrm{Pt}_{5}$ alloy rod with a diameter of $2 \mathrm{~mm}$. The $T_{\mathrm{g}}, T_{\mathrm{x}}$ and $\Delta T_{\mathrm{x}}$ are $875 \mathrm{~K}$, $925 \mathrm{~K}$ and $50 \mathrm{~K}$, respectively, and the total heat release upon devitrification of $-55 \mathrm{~J} / \mathrm{g}$ is close to that of the ribbon sample.

\subsection{Devitrification of Ni-Nb-Ti-M alloys}

The $\mathrm{Ni}_{55} \mathrm{Nb}_{25} \mathrm{Ti}_{15} \mathrm{M}_{5}$ glassy alloys showed essentially the same devitrification behavior as that of the $\mathrm{Ni}_{60} \mathrm{Nb}_{25} \mathrm{Ti}_{15}$ alloy, i.e. primary formation of the $\mathrm{Ni}(\mathrm{Ti}, \mathrm{Nb})$ and $\mathrm{Ni}_{3} \mathrm{Nb}$ phases (Fig. 12).

Thus, contrary to $\mathrm{Cu}$-based alloys the addition of noble metals does not alter the devitrification behavior of the Nibased alloys. 


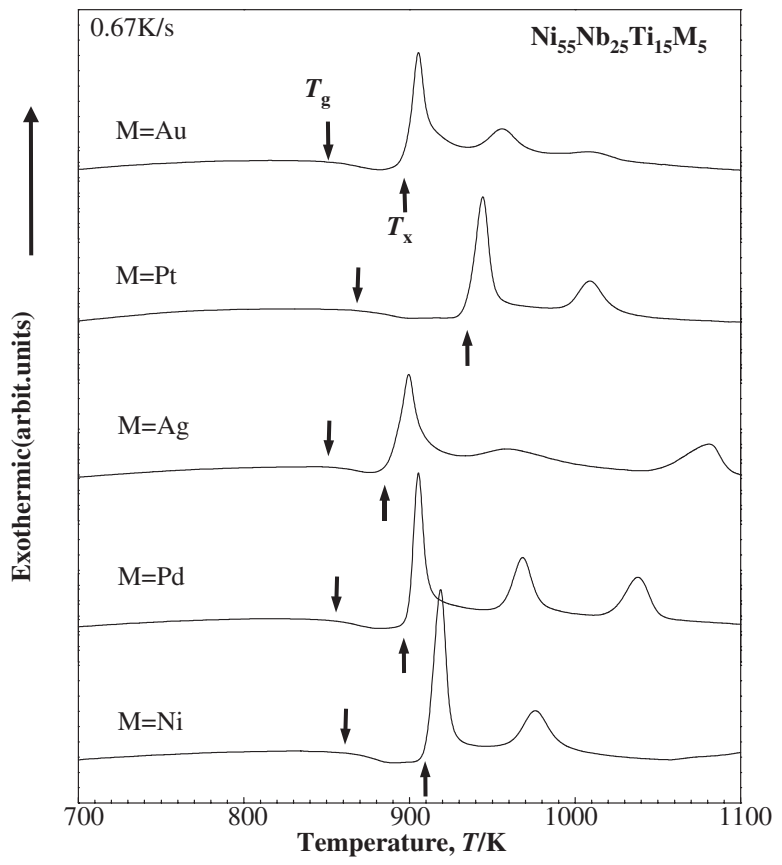

Fig. 6 DSC curves of $\mathrm{Ni}_{55} \mathrm{Nb}_{25} \mathrm{Ti}_{15} \mathrm{M}_{5}(\mathrm{M}=\mathrm{Pd}, \mathrm{Ag}, \mathrm{Pt}, \mathrm{Au})$ glassy alloys.

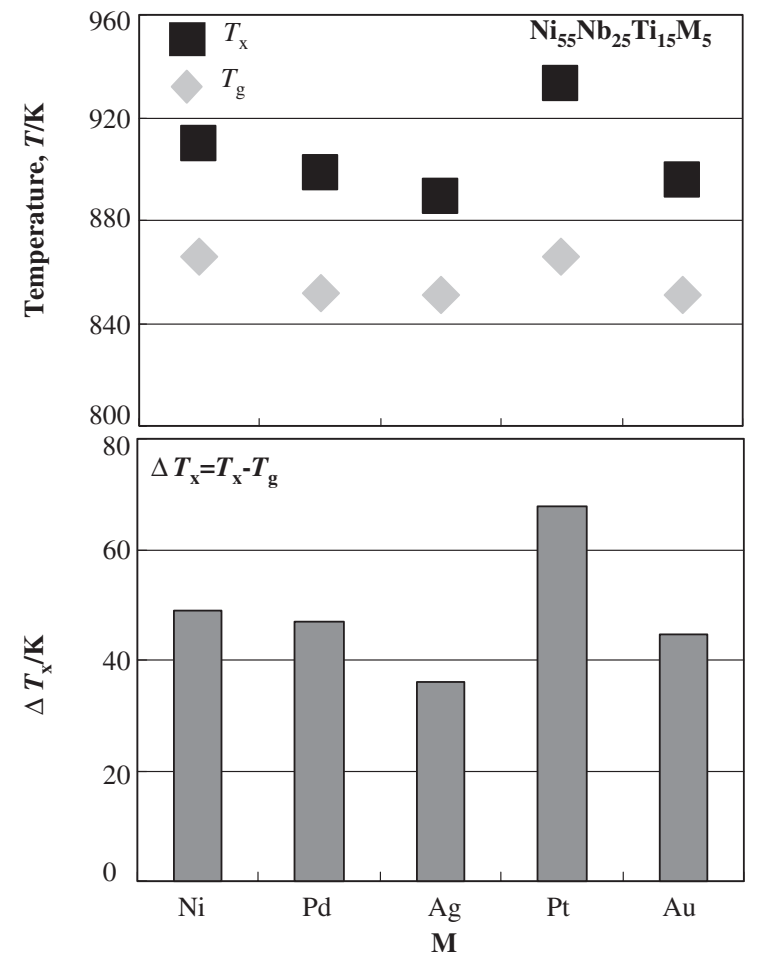

Fig. 7 Glass transition temperature $\left(T_{\mathrm{g}}\right)$, crystallization temperature $\left(T_{\mathrm{x}}\right)$ and supercooled liquid region $\left(\Delta T_{\mathrm{x}}=T_{\mathrm{x}}-T_{\mathrm{g}}\right)$ of $\mathrm{Ni}_{55} \mathrm{Nb}_{25} \mathrm{Ti}_{15} \mathrm{M}_{5}$ $(\mathrm{M}=\mathrm{Pd}, \mathrm{Ag}, \mathrm{Pt}, \mathrm{Au})$ glassy alloys.

\section{Discussions}

Both $\mathrm{Ni}(\mathrm{Ti}, \mathrm{Nb})$ phase and $\mathrm{Ni}_{3} \mathrm{Nb}$ phase are observed in the sample heat treated by HT1 regime (Fig. 2). These phases also exist after the completion of the first exothermic peak. It follows that the competitive nucleation and growth of these

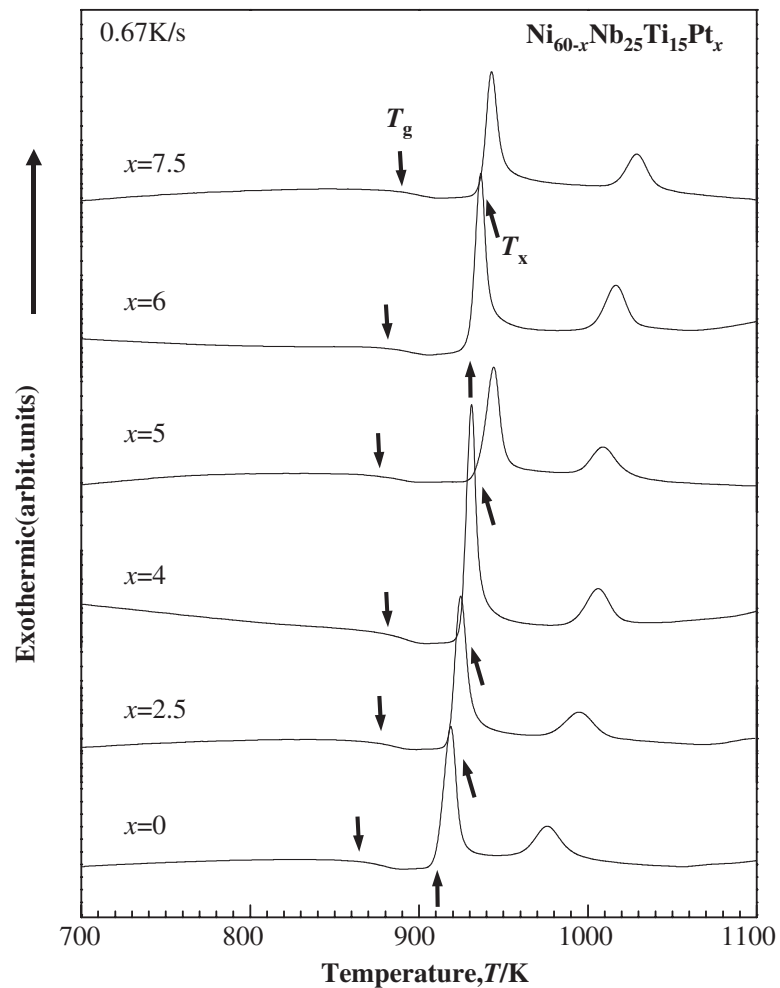

Fig. 8 DSC curves of $\mathrm{Ni}_{60-x} \mathrm{Nb}_{25} \mathrm{Ti}_{15} \mathrm{Pt}_{x}$ ( $x=0$ to 7.5 at $\%$ ) glassy alloys.

two phases takes place from the supercooled liquid at the first exothermic reaction and the $\mathrm{Ni}(\mathrm{Ti}, \mathrm{Nb})$ phase precipitates first.

Here one should notice that the $\mathrm{Ni}_{60} \mathrm{Nb}_{25} \mathrm{Ti}_{15}$ glassy alloy in as-solidified state does not have pre-existing nuclei (Fig. 13) $\mathrm{Ni}(\mathrm{Ti}, \mathrm{Nb})$ and $\mathrm{Ni}_{3} \mathrm{Nb}$ phases transform to the equilibrium $\mathrm{Ni}_{6} \mathrm{Nb}_{7}, \mathrm{Ni}_{9} \mathrm{NbTi}_{2}$ and $\mathrm{Ni}_{11} \mathrm{Nb}_{3} \mathrm{Ti}_{6}$ phases on further heating. Cubic $\mathrm{Ni}(\mathrm{Ti}, \mathrm{Nb})$ phase completely disappeared upon heating for $30 \mathrm{~min}$ at $1173 \mathrm{~K}$.

The Pt addition improves glass-forming ability (GFA) of the $\mathrm{Ni}_{60} \mathrm{Nb}_{25} \mathrm{Ti}_{15}$ alloy. The bulk glassy samples obtained for $\mathrm{Ni}_{55} \mathrm{Nb}_{25} \mathrm{Ti}_{15} \mathrm{Pt}_{5}$ alloy have a critical diameter of about $2.5 \mathrm{~mm}$. This result is in good correlation with the largest $\Delta T_{\mathrm{x}}$ which is obtained for the sample with the highest GFA among the studied alloys. The reason may be connected with highly negative mixing enthalpy in liquid in Ti-Pt and $\mathrm{Nb}-\mathrm{Pt}$ atomic pairs of -74 and $-67 \mathrm{~kJ} / \mathrm{mol}$, respectively. $\mathrm{Ni}-\mathrm{Pt}$ atomic pair also has a negative mixing enthalpy of $-5 \mathrm{~kJ} /$ mol. Moreover, Pt has an atomic size $(0.137 \mathrm{~nm})$ larger than that of $\mathrm{Ni}(0.125 \mathrm{~nm})$. All these factors are favorable for improving glass-forming ability. Surprisingly $\mathrm{Ni}_{55} \mathrm{Nb}_{25}$ $\mathrm{Ti}_{15} \mathrm{Pt}_{5}$ alloy has slightly lower $T_{\mathrm{g}} / T_{1}$ ratio (Fig. 9) compared to some other Ni-Nb-Ti-Pt alloys. It indicates that for these alloys $\Delta T_{\mathrm{x}}$ is a better index of glass-forming ability than $T_{\mathrm{g}} / T_{1}$ ratio.

Contrary to the $\mathrm{Cu}$-based alloys studied earlier ${ }^{15,16,18,19)}$ the addition of noble metals does not alter devitrification behavior of Ni-Nb-Ti alloys. Moreover, the addition of $\mathrm{Ni}$ to $\mathrm{Cu}-\mathrm{Zr}-\mathrm{Ti}$ system causes precipitation of the equilibrium $(\mathrm{Ni}, \mathrm{Cu})_{10} \mathrm{Zr}_{7}$ phase directly from the supercooled liquid at more than 5 at $\%$ of $\mathrm{Ni}$ content ${ }^{17,18)}\left(\mathrm{Ni}_{10} \mathrm{Zr}_{7}\right.$ phase forms primarily in the Ni-Zr-Ti alloy on devitrification) ${ }^{19)}$ and no 

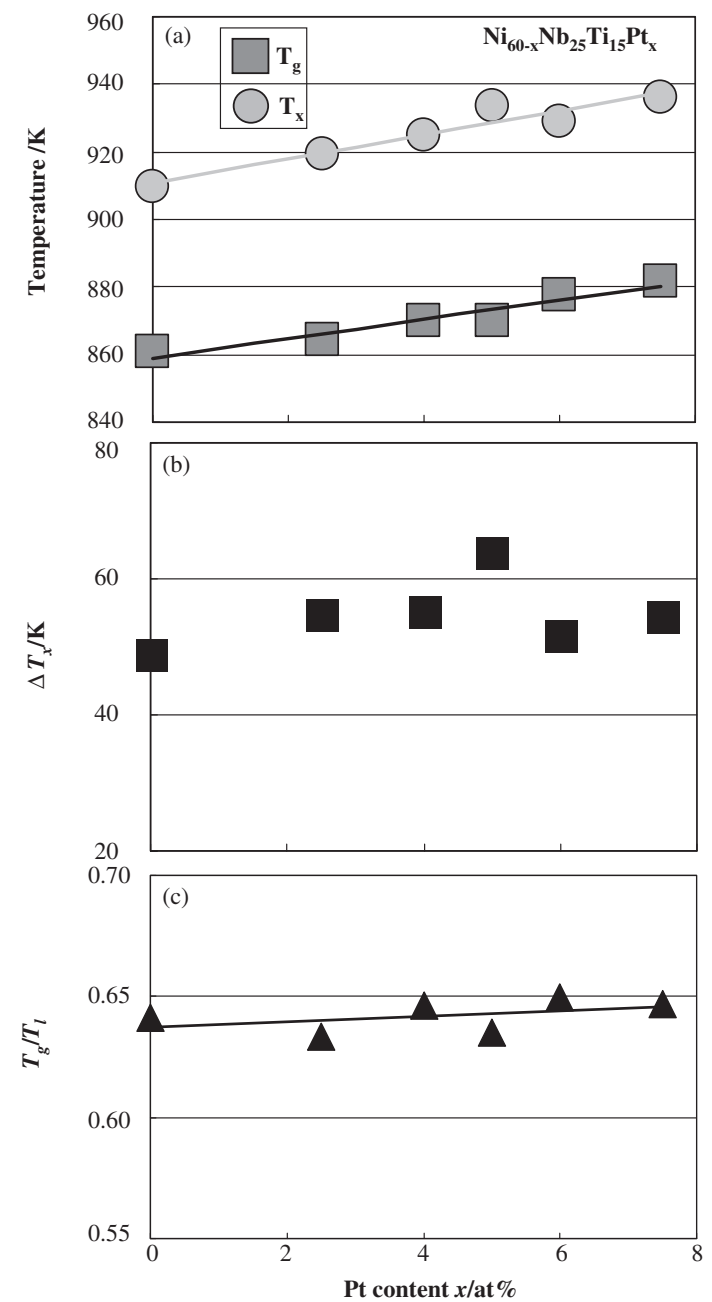

Fig. 9 (a) $T_{\mathrm{g}}, T_{\mathrm{x}}$, (b) $\Delta T_{\mathrm{x}}$ and (c) $T_{\mathrm{g}} / T_{1}$ as a function of Pt content for the $\mathrm{Ni}_{60-x} \mathrm{Nb}_{25} \mathrm{Ti}_{15} \mathrm{Pt}_{x}(x=0$ to 7.5$)$ glassy alloys.

formation of the icosahedral phase is observed in the $\mathrm{Ni}-\mathrm{Zr}$ Ti-Pd alloy. ${ }^{20)}$ This is in consistent with the previous data that the icosahedral phase is formed more readily in $\mathrm{Zr}-\mathrm{Cu}$ alloys than in $\mathrm{Zr}-\mathrm{Ni}$ ones. ${ }^{20,21)}$

\section{Conclusions}

(1) In the $\mathrm{Ni}_{60} \mathrm{Nb}_{25} \mathrm{Ti}_{15}$ alloy, $\mathrm{Ni}(\mathrm{Ti}, \mathrm{Nb})$ and $\mathrm{Ni}_{3} \mathrm{Nb}$ phases precipitate primarily from the supercooled liquid by the competitive nucleation and growth. The former phase has a primitive cubic lattice with a lattice parameter of $a=$ $0.293 \mathrm{~nm}$. It is a solid solution of $\mathrm{Nb}$ in a cubic NiTi phase.

(2) $\mathrm{Ni}(\mathrm{Ti}, \mathrm{Nb})$ and $\mathrm{Ni}_{3} \mathrm{Nb}$ phases are transform upon further heating to the $\mathrm{Ni}_{6} \mathrm{Nb}_{7}, \mathrm{Ni}_{9} \mathrm{NbTi}_{2}$ and $\mathrm{Ni}_{11} \mathrm{Nb}_{3} \mathrm{Ti}_{6}$ phases. $\mathrm{Ni}_{4} \mathrm{Ti}_{3}$ phase was also formed as a result of transformation of the $\mathrm{Ni}(\mathrm{Ti}, \mathrm{Nb})$ cubic phase.

(3) The Pt addition improves glass-forming ability (GFA) of the $\mathrm{Ni}_{60} \mathrm{Nb}_{25} \mathrm{Ti}_{15}$ alloy. The $\mathrm{Ni}_{55} \mathrm{Nb}_{25} \mathrm{Ti}_{15} \mathrm{Pt}_{5}$ amorphous alloy with the largest $\Delta T_{\mathrm{x}}$ has a critical diameter of about $2.5 \mathrm{~mm}$. The reason may be connected with the highly negative mixing enthalpy in Ti-Pt and $\mathrm{Nb}-\mathrm{Pt}$ atomic pairs. $\Delta T_{\mathrm{x}}$ is better index of the glass-firming ability of the Ni-NbTi-Pt alloys than $T_{\mathrm{g}} / T_{1}$ ratio.

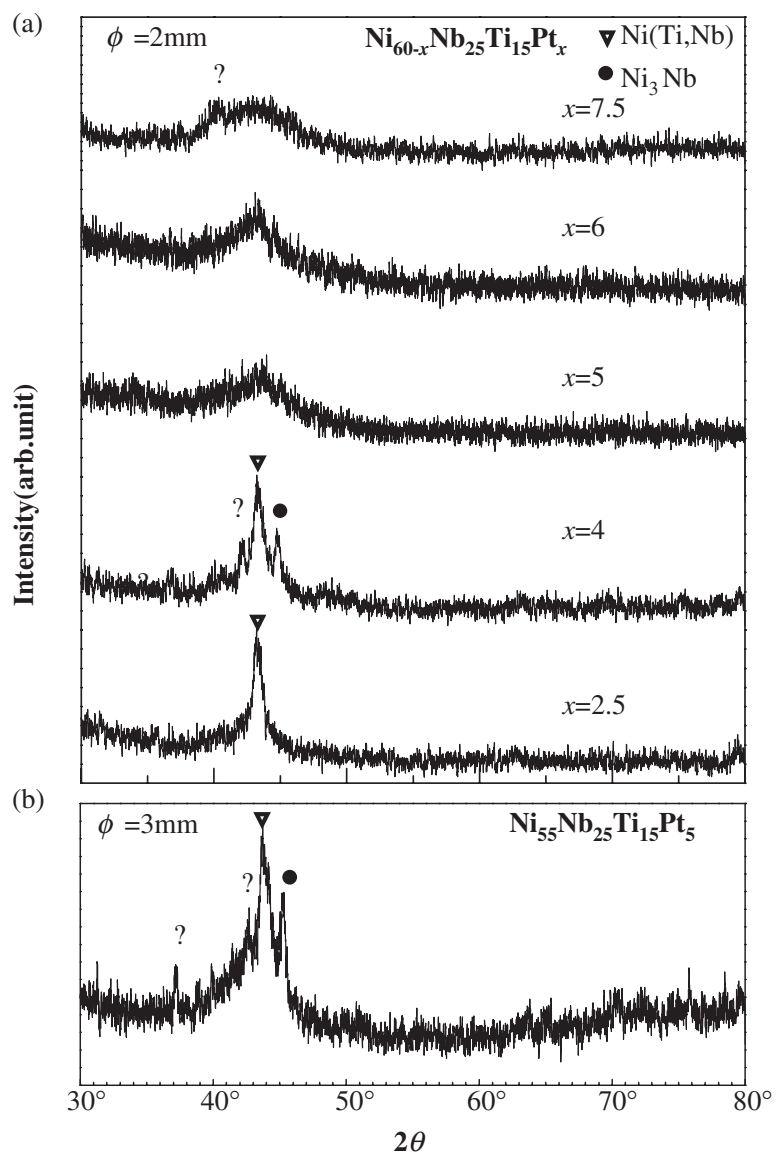

Fig. $10 \mathrm{X}$-ray diffraction patterns of $\mathrm{Ni}_{60-x} \mathrm{Nb}_{25} \mathrm{Ti}_{15} \mathrm{Pt}_{x}(x=2.5$ to 7.5$)$ bulk samples with a diameters of $2 \mathrm{~mm}$ (a), and $\mathrm{Ni}_{55} \mathrm{Nb}_{25} \mathrm{Ti}_{15} \mathrm{Pt}_{5}$ alloy rod with a diameter of $3 \mathrm{~mm}$ (b).

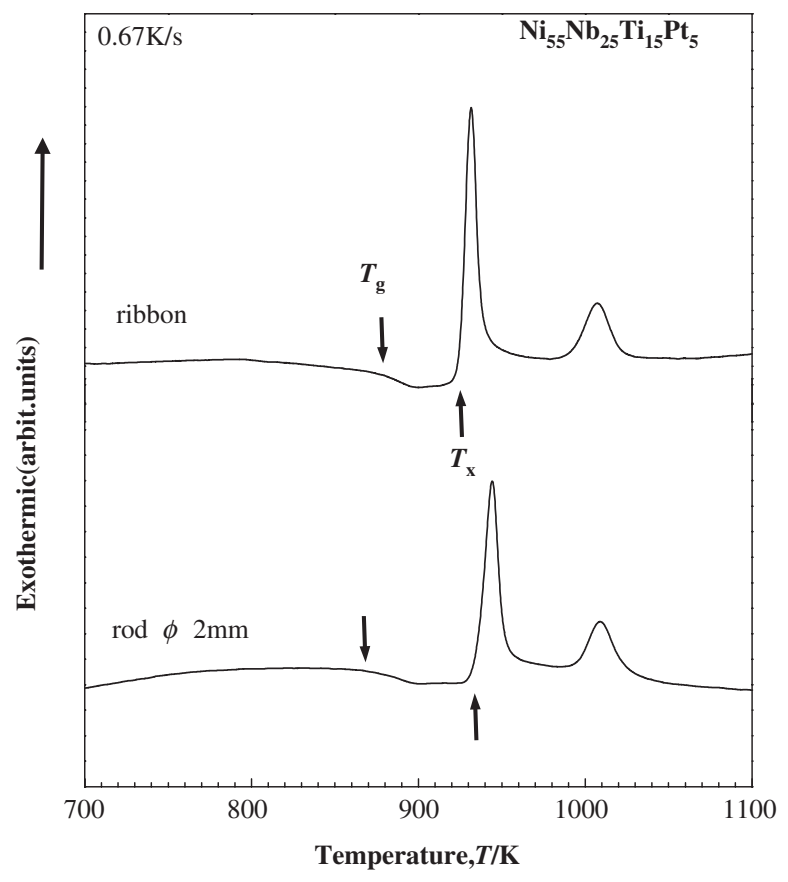

Fig. 11 DSC curves for $\mathrm{Ni}_{55} \mathrm{Nb}_{25} \mathrm{Ti}_{15} \mathrm{Pt}_{5}$ bulk alloy with a diameter of $2 \mathrm{~mm}$. The data of the melt-spun ribbon are also shown for comparison. 


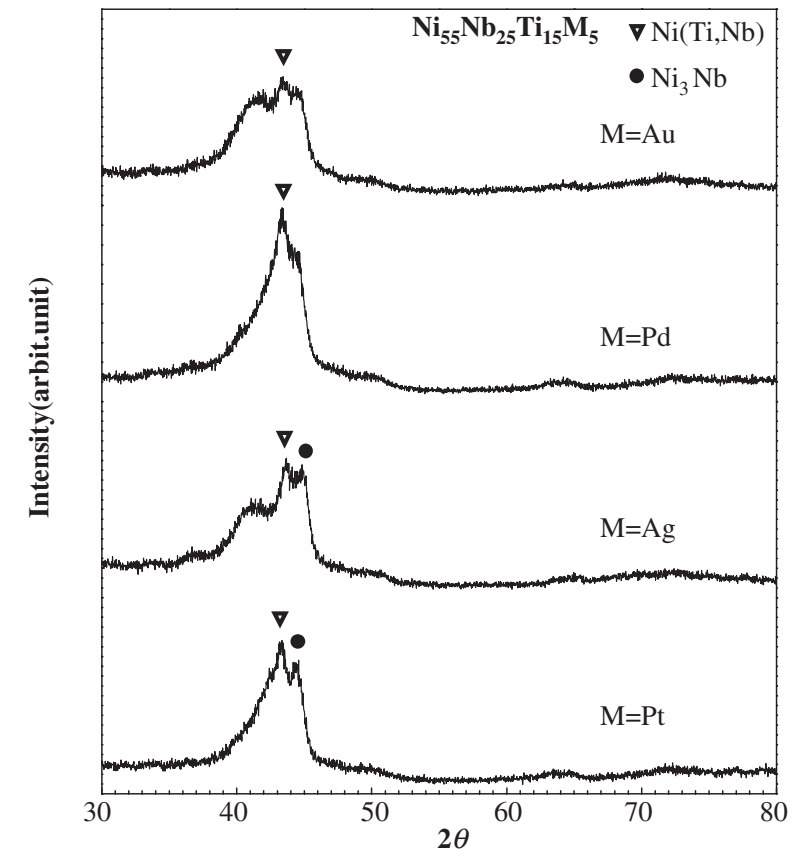

Fig. $12 \mathrm{XRD}$ results of $\mathrm{Ni}_{55} \mathrm{Nb}_{25} \mathrm{Ti}_{15} \mathrm{M}_{5}(\mathrm{M}=\mathrm{Pt}, \mathrm{Ag}, \mathrm{Pd}, \mathrm{Au})$ alloy annealed at the first peak temperature $\left(T_{\mathrm{p}}\right)$ for $300 \mathrm{ks}$.

\section{Acknowledgements}

This work was partially supported by the Grant-in-Aid of Ministry of Education, Sports, Culture, Science and Technology, Japan, Priority Area on "Materials Science on Bulk Metallic Glasses".

\section{REFERENCES}

1) A. Inoue: Mater. Trans., JIM 36 (1995) 866.

2) A. Inoue: Acta Mater. 48 (2000) 279-306.

3) W. L. Johnson: MRS Bull 24 (1999) 42.

4) Y. C. Kim, W. T. Kim and D. H. Kim: Mater. Sci. Eng. A 375-377 (2004) 127.

5) S. Yi, T. G. Park and D. H. Kim: J. Mater. Res. 15 (2000) 2425-2430.

6) J. K. Lee, S. H. Kim, S. Yi, W. T. Kim and D. H. Kim: J Non-Cryst Solids 291 (2001) 132-136.

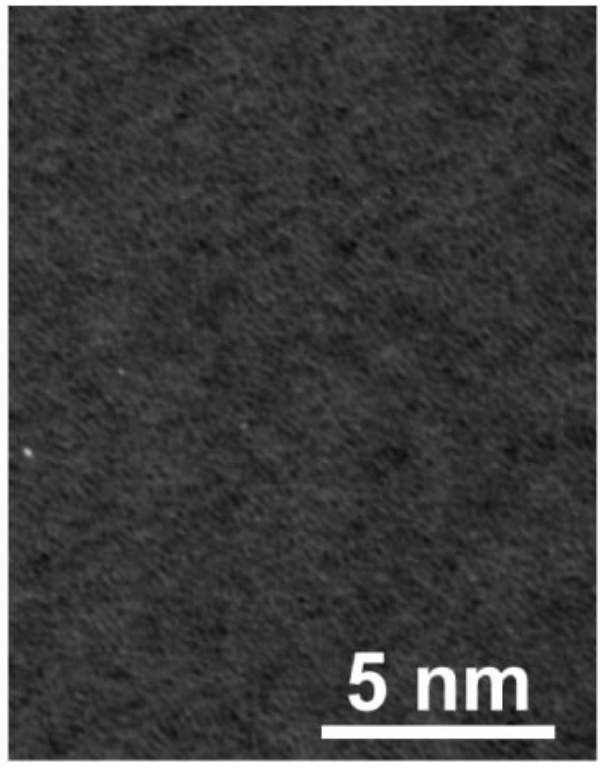

Fig. 13 High-resolution TEM image of the $\mathrm{Ni}_{60} \mathrm{Nb}_{25} \mathrm{Ti}_{15}$ glassy alloy in as-solidified state.

7) H. Choi-Yim, D. Xu and W. L. Johnson: Appl: Phys. Lett. 82 (2003) 1030 .

8) T. Zhang and A. Inoue: Mater. Trans. 43 (2002) 708

9) A. Inoue, W. Zhang and T. Zhang: Mater. Trans. 43 (2002) 1952.

10) W. Zhang and A. Inoue: Mater. Trans. 43 (2002) 2342-2345.

11) D. V. Louzguine and A. Inoue: Scr. Mater. 48 (2003) 1325.

12) D. V. Louzguine and A. Inoue: J. Alloys Compd. 361 (2003) 153.

13) A. Inoue, J. Saida, M. Matsushita and T. Sakurai: Mater. Trans. 41 (2000) 362-365.

14) A. Inoue, T. Zhang, M. Matsushita, M. W. Chen and T. Sakurai: Mater. Trans., JIM 40 (1999) 1137-1143.

15) A. Inoue, T. Zhang, M. Matsushita, M. W. Chen and T. Sakurai: Mater. Trans., JIM 40 (1999) 1181-1184.

16) T. Zhang, T. Yamamoto and A. Inoue: Mater. Trans. 43 (2002) 3222.

17) D. V. Louzguine and A. Inoue: Mater. Sci. Forum/Journal of Metastable \& Nanocrystalline Materials, 31 (2003) 15-16.

18) D. V. Louzguine and A. Inoue: J. Non-Cryst. Solids 325 (2003) 187.

19) D. V. Louzguine and A. Inoue: J. Non-Cryst. Solids, in Press.

20) J. Saida, M. Matsushita and A. Inoue: Intermetallics 10 (2002) 10891098.

21) M. Leonhardt, W. Löser and H.-G. Lindenkreuz: Acta Mater. 47 (1999) 2961-2968. 